\title{
GAMBARAN ANGKA LEMPENG TOTAL DAN IDENTIFIKASI BAKTERI Escherichia coli PADA LOLOH BUNGA TELENG DI DESA PENGLIPURAN KECAMATAN BANGLI
}

\author{
Ageng Pertiwi Yudani Devy W ${ }^{1}$, Nyoman Mastra $^{2}$, Nur Habibah ${ }^{3}$ \\ Jurusan Teknologi Laboratorium Medis \\ nyoman_mastra@yahoo.co.id
}

\begin{abstract}
Background : Teleng flower herb is a processed beverage made from teleng flower which is popular as a traditional drink from Penglipuran. As one of the beverage products, teleng flower herbs obtain consent from the BPOM before distributed and consumed. Aims : this study to analyze the quality of microbiology of teleng flower herb. The analyzed were total plate count ( ALT) and E. coli bacteria identification. Method : descriptive research with laboratory examinations which at the Bacteriology Laboratory. The 7 samples were obtained from producers with three times repetition so that it became 21 samples with sampling techniques were saturated sampling. Result : The ALT examination results show that 5 samples $(71.4 \%)$ are not qualify and 2 samples (28.6\%) are qualify based on BPOM Regulation Number 16 In 2016. The obtained results of E. coli identification show that there were 4 (57.1\%) contain of E. coli and 3 samples (42.9\%) are not contains of E. coli. Conclusion : It can be concluded that most of the hygiene of teleng flower herb at Penglipuran Village does not meet the requirements.
\end{abstract}

Key words: teleng flower herb, microbiological quality, total plate count, Escherichia coli

\section{PENDAHULUAN}

Desa Penglipuran merupakan salah satu objek wisata yang terkenal di Bali. Desa Penglipuran menawarkan kearifan lokal yang masih dijunjung tinggi oleh masyarakat Bali. Desa tersebut menjadi salah satu desa adat di Bali yang masih kuat menjaga tradisi, ritual adat dan berbagai kearifan lokal lainnya. Desa Penglipuran selain unik dan asri, juga memiliki minuman tradisional yakni loloh cem cem, loloh kunyit dan loloh Bunga Teleng ${ }^{1}$.

Loloh Bunga Teleng ini dibuat dari hasil rebusan bunga teleng yang dalam bahasa Indonesia disebut bunga telang, dengan nama latinnya yaitu Clitoria ternatea. Bunga Teleng ini adalah tumbuhan yang merambat yang biasa ditemukan di daerah yang memiliki iklim tropis. Bunga teleng banyak dieksplorasi dan menunjukkan sangat potensial untuk meningkatkan kesehatan manusia ${ }^{2}$

Jika ditinjau dari segi kesehatan, makanan dan minuman selain berfungsi sebagai sumber energi, zat pembangun dan zat pengatur, juga mempunyai peran dalam penyebaran penyakit. Terjadinya penyakit yang masuk ke dalam tubuh melalui makanan dan minuman yang disebabkan oleh cemaran biologi adalah sebanyak

Meditory | ISSN Online : 2549-1520, ISSN Cetak : 2338 - 1159, Vol. 9, No. 1, Juni 2021 
Devy, A.P.Y., dkk.,: Gambaran Angka Lempeng Total Dan Identifikasi Bakteri Escherichia coli Pada Loloh Bunga Teleng Di Desa Penglipuran Kecamatan Bangli

$36,7 \%$ cemaran kimia sebesar $20,2 \%$ dan makanan kadaluarsa sebesar $13,8 \%{ }^{3}$.

Mikroorganisme terutama bakteri coliform sering ditemukan pada makanan dan minuman yang kurang higienis. Bahan makanan tersebut banyak tercemar karena diolah secara sederhana. Bakteri Coliform dapat mencemari dan menyebabkan pembusukan bahan makanan dan minuman yang penyimpanannya tidak cukup baik ${ }^{4}$. Pangan dapat beracun karena telah terkontaminasi oleh bakteri patogen yang kemudian dapat tumbuh dan berkembang biak selama penyimpanan, sehingga bakteri tersebut mampu memproduksi toksin yang berbahaya bagi manusia. Bakteri yang terkait dengan keracunan makanan di antaranya adalah Escherichia coli enteropatogenik. Salah satu bakteri patogen enterik adalah Escherichia coli yang sering disingkat E. coli yang merupakan salah satu jenis spesies utama bakteri basil gram negatif. Disebut enterik karena bakteri Escherichia coli dalam keadaan normalnya yang hidup di dalam usus besar manusia ${ }^{5}$.

Loloh bunga teleng yang dijual di pasaran merupakan salah satu hasil produksi

\section{METODE}

Jenis penelitian yang digunakan adalah deskriptif untuk menghitung jumlah angka lempeng total dan mengidentifikasi bakteri Escherichia coli pada loloh bunga teleng di Desa Penglipuran Kecamatan minuman tradisional Desa Penglipuran. Minuman loloh bunga teleng yang belum diketahui kualitasnya itu perlu dilakukan pemeriksaan sebelum diedarkan ke pasar atau produsen lainnya guna menjamin kualitas dan dapat memenuhi syarat kualitas minuman dari Badan Pengawas Obat dan Makanan (BPOM). Berdasarkan penelitian pemeriksaan kualitas mikrobiologis minuman tradisional (loloh) yang dilakukan oleh Dinas Kesehatan Kabupaten Bangli pada tahun 2016 (Dalam ) $^{6}$, salah satu hasilnya adalah ditemukannya 6 dari sampel yang diperiksa 2 diantaranya positif Escherichia coli, dan 1 sampel yang negative Escherichia coli, namun coliform melebihi ambang batas dan sejauh ini belum ada yang melakukan uji cemaran bakteri terkait dengan keamanan dari loloh bunga teleng. Berdasarkan hal tersebut maka peneliti tertarik untuk melakukan penelitian mengenai angka lempeng total dan identifikasi bakteri Escherichia coli pada loloh bunga teleng di Desa Penglipuran Kecamatan Bangli, Kabupaten Bangli.

Bangli. Pengambilan sampel dalam penelitian ini adalah Non Probability secara sampling jenuh. Data yang digunakan merupakan data primer dan data sekunder. Teknik analisi data dan penyajian data adalah secara deskriptif dan disajikan dalam bentuk tabel dan uarian kalimat. 
Devy, A.P.Y., dkk.,: Gambaran Angka Lempeng Total Dan Identifikasi Bakteri Escherichia coli Pada Loloh Bunga Teleng Di Desa Penglipuran Kecamatan Bangli

\section{HASIL DAN PEMBAHASAN}

HASIL

1) Pemeriksaan angka lempeng total

Penulis melakukan pemeriksaan angka lempeng total terhadap loloh bunga teleng pada tujuh produsen dengan pengulangan tiga kali sehingga loloh bunga teleng yang diperiksa sebanyak 21 sampel loloh bunga teleng di Desa Penglipuran Kecamatan Bangli untuk mengetahui kualitas loloh bunga teleng, hasil pemeriksaan tersebut dijabarkan sebagai berikut:

Tabel 1

Hasil Pemeriksaan Angka Lempeng Total pada Loloh Bunga Teleng di Desa Penglipuran Kecamatan Bangli

\begin{tabular}{|c|c|c|c|c|c|c|c|}
\hline \multirow[t]{2}{*}{ No } & \multirow{2}{*}{$\begin{array}{c}\text { Kode } \\
\text { sampel }\end{array}$} & \multicolumn{3}{|c|}{ Pengulangan } & \multirow[t]{2}{*}{ Jumlah } & \multirow{2}{*}{$\begin{array}{l}\text { Rerata } \\
\text { koloni/m } \\
\text { L }\end{array}$} & \multirow[t]{2}{*}{ Persyaratan } \\
\hline & & I & II & III & & & \\
\hline 1 & (01) & $20,9 \times 10^{5}$ & $54,95 \times 10^{5}$ & $22,7 \times 10^{5}$ & $98,55 \times 10^{5}$ & $32,85 \times 10^{5}$ & $\begin{array}{c}\text { Tidak } \\
\text { Memenuhi }\end{array}$ \\
\hline 2 & $(02)$ & $60,4 \times 10^{5}$ & $31,85 \times 10^{5}$ & $55,8 \times 10^{5}$ & $1.48,05 \times 10^{5}$ & $49,35 \times 10^{5}$ & $\begin{array}{c}\text { Syarat } \\
\text { Tidak } \\
\text { Memenuhi }\end{array}$ \\
\hline 3 & (03) & $51,05 \times 10^{5}$ & $28,04 \times 10^{5}$ & $47,8 \times 10^{5}$ & $1.26,89 \times 10^{5}$ & $42,29 \times 10^{5}$ & $\begin{array}{c}\text { Syarat } \\
\text { Tidak } \\
\text { Memenuhi }\end{array}$ \\
\hline 4 & (04) & $48 \times 10^{5}$ & $28,24 \times 10^{5}$ & $17,05 \times 10^{5}$ & $93,29 \times 10^{5}$ & $31,09 \times 10^{5}$ & $\begin{array}{c}\text { Syarat } \\
\text { Tidak } \\
\text { Memenuhi }\end{array}$ \\
\hline 5 & $(05)$ & $54,2 \times 10^{5}$ & $30,73 \times 10^{5}$ & $55 \times 10^{5}$ & $1.39,93 \times 10^{5}$ & $46,64 \times 10^{5}$ & $\begin{array}{l}\text { Tidak } \\
\text { Memenuhi } \\
\text { Syarat }\end{array}$ \\
\hline 6 & (06) & $3,4 \times 10^{2}$ & $3,7 \times 10^{2}$ & $3,1 \times 10^{2}$ & $10,2 \times 10^{2}$ & $3,4 \times 10^{2}$ & $\begin{array}{c}\text { Memenuhi } \\
\text { syarat }\end{array}$ \\
\hline 7 & (07) & $5 \times 10^{2}$ & $5,1 \times 10^{2}$ & $4,9 \times 10^{2}$ & $1,5 \times 10^{3}$ & $5 \times 10^{2}$ & $\begin{array}{c}\text { Memenuhi } \\
\text { syarat }\end{array}$ \\
\hline
\end{tabular}

Berdasarkan hasil pemeriksaan bunga teleng yang memenuhi syarat angka lempeng total yang didapatkan pada kesehatan. penelitian ini yaitu $71,4 \%$ sampel loloh bunga teleng yang tidak memenuhi standar kesehatan dan sebanyak 28,6\% sampel loloh 
Devy, A.P.Y., dkk.,: Gambaran Angka Lempeng Total Dan Identifikasi Bakteri Escherichia coli Pada Loloh Bunga Teleng Di Desa Penglipuran Kecamatan Bangli

2) Identifikasi Escherichia coli

Penulis melakukan pemeriksaan identifikasi E.coli pada 21 sampel loloh bunga teleng yang dijual oleh 7 produsen di
Desa Penglipuran Kecamatan Bangli untuk mengetahui kualitas loloh bunga teleng, hasil pemeriksaan tersebut dijabarkan sebagai berikut:

Tabel 2

Hasil pemeriksaan Identifikasi E.coli pada Loloh Bunga Teleng di Desa Penglipuran Kecamatan Bangli

\begin{tabular}{ll}
\hline No & Identifikasi E.coli Patogen \\
\hline 1 & Positif \\
2 & Negatif \\
\hline & Total \\
\hline & Berdasarkan hasil pemeriksaam \\
yang dilakukan didapatkan yaitu sebanyak 4 \\
produsen (57,1\%) \\
patogen dan sebanyak 3 produsen (42,9\%) \\
negatif terhadap E.coli patogen.
\end{tabular}

\section{PEMBAHASAN}

1. Angka lempeng total

Loloh bunga teleng dapat terkontaminasi oleh bakteri mengingat komposisinya yang dibuat dengan menggunakan bahan dasar bunga teleng, gula, dan air yang akan meningkatkan resiko pertumbuhan bakteri kemudian akan dapat mempengaruhi kualitas dari minuman loloh bunga teleng. Kualitas loloh bunga teleng yang dijual oleh produsen di Desa Penglipuran Kecamatan Bangli sebagian besar tidak memenuhi syarat kesehatan yaitu sebesar $71,4 \%$ yang didapatkan dari hasil pemeriksaan angka lempeng total apabila
Jumlah Sampel Persentase (\%)

57,1

3

42,9

dikonsumsi oleh masyarakat dapat menimbulkan beberapa penyakit seperti diare dan keracunan makanan.

Hasil pemeriksaan kualitas bakteri dengan parameter angka lempeng total pada loloh bunga teleng di Desa Penglipuran Kecamatan Bangli didapatkan hasil penelitian menunjukkan bahwa angka lempeng total dengan nilai terendah sebesar $3,4 \times 10^{2}$ koloni $/ \mathrm{mL}$ dan tertinggi sebesar $55 \times 10^{5}$ koloni/mL. Standar yang digunakan pada penelitian kali ini adalah ${ }^{7}$. Hasil pemeriksaan angka lempeng total yang didapatkan pada penelitian ini yaitu $71,4 \%$ sampel loloh bunga teleng yang tidak memenuhi standar kesehatan dan sebanyak 28,6\% sampel loloh bunga teleng yang memenuhi syarat kesehatan. Menurut ${ }^{8}$ ini dikarenakan faktor proses penyajian pada botol plastik yang kurang bersih dapat 
Devy, A.P.Y., dkk.,: Gambaran Angka Lempeng Total Dan Identifikasi Bakteri Escherichia coli Pada Loloh Bunga Teleng Di Desa Penglipuran Kecamatan Bangli

sebagai penyebab terkontaminasinya

minuman loloh bunga teleng tersebut.

Tempat penyimpanan dan penyajian yang tidak memenuhi syarat kesehatan akan memudahkan terjadinya kontaminasi oleh mikroorganisme. Cara pengolahan yang tidak benar juga dapat menjadi penyebab loloh bunga teleng tersebut tekontaminasi, apabila air yang digunakan produsen dimasak tetapi suhunya tidak sampai $100^{\circ} \mathrm{C}$ bisa menyebabkan bakteri tersebut tetap berada di air tersebut.

\section{Identifikasi Escherichia coli}

\section{Identifikasi Escherichia coli} dilakukan dengan pemeriksaan MPN yaitu pertama dengan melakukan test penduga atau presumptive test dengan menggunakan media Lactose Broth yang bertujuan untuk menduga adanya bakteri coliform yang mempunyai sifat mampu memfermentasikan laktosa dengan menghasilkan gas. Bakteri coliform yang diduga meliputi semua bakteri gram negatif tidak membentuk spora, selnya membentuk sel pendek, bersifat fakultatif anaerob akan membentuk gas dalam waktu 24 jam dari laktosa pada temperatur $37^{\circ}$ Celsius.

Hasil pemeriksaan pada test penduga dengan menggunakan media Lactose Broth yang didapatkan hasil yaitu positif terdapat gelembung gas pada semua sampel. Pengamatan hasil pada tabung positif dilakukan dengan mengamati perubahan warna pada sampel yang sebelumnya dicampurkan dengan media LB (Lactose Broth), atau dengan terbentuknya gelembung gas dalam tabung durham.

Test kedua yaitu test penegasan dalam hal ini bertujuan untuk menegaskan hasil positif dari test penduga yang menggunakan media Brilliant Green Lactose Bile Bronth (BGLB 2\%). Dari hasil pemeriksaan dengan test penegasan ini didapatkan hasil bahwa sampel loloh bunga teleng yang positif adanya bakteri coliform sebanyak 15 sampel loloh bunga teleng yang ditandai dengan adanya gelembung gas setelah diinkubasi pada suhu $37^{\circ} \mathrm{C}$ dan sebanyak 6 sampel yang negatif. Sedangkan positif adanya bakteri coli fekal atau yang bersifat patogen adalah sebanyak 12 sampel atau empat produsen $(57,1 \%)$ yang ditandai dengan adanya gelembung gas setelah diinkubasi pada suhu $44^{\circ} \mathrm{C}$ dan didapatkan sebanyak 9 sampel atau tiga produsen $(42,9 \%)$ yang memberikan hasil negatif.

Hasil dari data wawancara dan observasi pada produsen loloh bunga teleng yang mengenai higienitas dari 7 produsen loloh bunga teleng pada penelitian ini termasuk kurang baik, hal ini jika dilihat dari hasil pemeriksaan yang diperoleh yaitu angka lempeng total dan identifikasi E.coli hasil menunjukan tidak memenuhi syarat kesehatan sebesar $71,4 \%$ jika ditinjau dari identifikasi Escherichis coli sebanyak 57,1\% sampel loloh bunga teleng yang tidak memenuhi syarat kesehatan yang

Meditory | ISSN Online : 2549-1520, ISSN Cetak : 2338 - 1159, Vol. 9, No. 1, Juni 2021 
Devy, A.P.Y., dkk.,: Gambaran Angka Lempeng Total Dan Identifikasi Bakteri Escherichia coli Pada Loloh Bunga Teleng Di Desa Penglipuran Kecamatan Bangli

mengandung bakteri coli fekal atau bersifat patogen bagi yang mengonsumsinya ${ }^{7}$

Berdasarkan hasil observasi terdapat beberapa kendala dalam produksi loloh bunga teleng yaitu ketersediaan bahan baku selama ini bahan baku loloh bunga teleng yang digunakan dalam bentuk segar, sehingga jumlah produksi per hari loloh bunga teleng terbatas tergantung jumlah bahan baku yang tersedia. Sanitasi produsen loloh bunga teleng meliputi tempat pengolahan yang tidak memiliki ruang khusus untuk mengolah loloh bunga teleng sehingga pengolahan loloh bunga dilakukan di dapur ataupun di halaman rumah namun sebagian produsen telah memiliki ruang khusus dalam pengolahan loloh bunga teleng. Belum adanya standar baku (resep) dalam pembuatan loloh yang baku sehingga loloh yang dihasilkan memiliki kualitas dapat berbeda-beda terutama dari segi sensoris. Penggunaan bahan baku pembuatan loloh berdasarkan hasil perkiraan dari produsen sehingga tidak konsisten dalam pembuatan loloh bunga teleng. Penggunaan botol kemasan plastik yang disimpan tidak pada tempatnya sehingga memungkinkan untuk terkontaminasinya bakteri ${ }^{8}$. Hal itu dapat menyebabkan hasil pemeriksaan pada identifikasi bakteri Escherichia coli negatif namun pada pemeriksaan angka lempeng total tidak memenuhi syarat kesehatan. Sampel yang negatif bakteri E.coli patogen namun positif pada jumlah bakteri coliform karena keberadaan coliform melebihi nilai batas maksimum dalam suatu produk minuman.

\section{SIMPULAN DAN SARAN}

Angka lempeng total pada loloh bunga teleng di Desa Penglipuran Kecamatan Bangli sebanyak 7 produsen sampel yang diperiksa dan sebanyak lima produsen $71,4 \%$ tidak memenuhi syarat kesehatan dan sebanyak dua produsen $28,6 \%$ memenuhi syarat kesehatan berdasarkan ${ }^{7}$. Nilai angka lempeng total yang tidak memenuhi syarat melebihi dari $10^{3}$ koloni/mL. Identifikasi Escherichia coli yang dilakukan pada 7 produsen loloh bunga teleng didapatkan hasil sebanyak $57,1 \%$ positif Escherichia coli yang bersifat patogen dan $42,9 \%$ negatif.

\section{DAFTAR PUSTAKA}

1. Muliawan, I. W. 2017. Kearifan masyarakat desa penglipuran kabupaten bangli dalam melestarikan tanaman bambu dan aplikasinya sebagai bahan bangunan,6,3443. Ejournal Vol6,No1. https://ejournal. warmadewa.ac.id /index.php/paduraksa/article/view/457. Diakses pada 17 Desember 2018.

2. Suganda, T., dan Adhi, R. 2017. Uji Pendahuluan Efek Fungisida Bunga Kembang ( Clitoria ternatea L .) terhadap Jamur Fusarium oxysporum $\mathrm{f}$. sp . cepae Penyebab Penyakit Moler pada Bawang Merah, 28(3), 136-140. Jurnal Vol 28, No 3. http://jurnal.unpad.ac.id/agrikultura/artic le/view/15746. Diakses pada 9 Mei 2019

Meditory | ISSN Online : 2549-1520, ISSN Cetak : 2338 - 1159, Vol. 9, No. 1, Juni 2021 
Devy, A.P.Y., dkk.,: Gambaran Angka Lempeng Total Dan Identifikasi Bakteri Escherichia coli Pada Loloh Bunga Teleng Di Desa Penglipuran Kecamatan Bangli

3. BPOM RI, 2008. Pengujian Mikrobiologi Makanan. InfoPOM Pengawas Obat dan Makanan Republik Indonesia Vol. 9, No. 2. Maret 2008. [cited2014 Sep 13].Availablefrom:http://perpustakaan.p om.go.id/KoleksiLainnya/Buletin\%20In fo \%20POM/0208.pdf. Diakses pada 25 November 2018

4. Yulistiani R, 2010. Studi Daging Ayam : Perubahan Organoleptik dan Pola Pertumbuhan Bakteri. Jurnal Teknologi Pertanian, vol. 4, no.1, hal. 27-36. https://jtp.ub.ac.id/index.php/jtp/article/d ownload/304/375. Diakses pada 5 Desember 2018.

5. Ekawati, Yusmiati, dan Hamidi, 2017. Deteksi Escherichia Coli Patogen Pada Pangan Menggunakan Metode Konvensional Dan Metode Multiplex Pcr. SainHealth, 1(2), 23-31. Retrieved from https://ejournal.umaha.ac.id/index.php/sainhealt h/article/view/107. Diakses pada 3 Januari 2019.

6. Wirawan, G. R., 2017. Keamanan Mikrobiologis Minuman Tradisional Loloh Cemcem Di Desa Wisata Penglipuran. Program Studi Kesehatan Masyarakat Fakultas Kedokteran Universitas Udayana, . Skripsi. https://sinta.unud.ac.id/uploads/dokume n_dir/84860d984f27165ce4e19aa6ae2a9 935.pdf. Diakses pada 19 November 2018.

7. ___ 2016. Peraturan Kepala Badan Pengawas Obat Dan Makanan Republik Indonesia Nomor 16 Tahun 2016 Tentang Kriteria Mikrobiologi Dalam PanganOlahan.http://standarpangan.pom .go.id/dokumen/peraturan/2016/PerKa_ BPOM_No_16_Tahun_2016_tentang_K riteria_Mikrobiologi_dalam_Pangan_Ol ahan.pdf. Diakses pada 25 November 2018

8. Syarifin, Amintarti, S. dan Halang, B. 2015. Deteksi Coliform dan Escherichia coli pada Susu Kedelai yang Dijual di Kawasan Kecamatan Banjarmasin Utara. Wahana-Bio, XIV, pp. 117-133. Available at: ppjp. unlam.ac.id /journal/index.php/wb/article/download/ 2172/1907\%0A. Diakses pada 9 Mei 2019.

9. Kartika Pratiwi I Desak Pt, Suter I Ketut, Sandhi W Putu Ari, Sri Wiadnyani A.A. Istri, 2015. Prevalensi Cemaran Mikrobiologis Dan Logam Berat Pada Minuman Tradisional (Lolo)DalamUpaya. https://sinta.unud.ac .id/uploads/dokumen_dir/84860d984f27 165ce4e19aa6ae2a9935.pdf. Diakses pada 9 Mei 2019. 